EUROPEAN UNIVERSITY INSTITUTE, FLORENCE DEPARTMENT OF POLITICAL AND SOCIAL SCIENCES

EUI WORKING PAPER No. $88 / 366$ THE THREE POLTICAL ECONOMIES OF THE WELFARE STATE by GÖSTA ESPING-ANDERSEN 
All rights reserved.

$320 \quad$ No part of this paper may be reproduced in any form (US) without permission of the author.

EUR

Gösta Esping-Andersen

Printed in Italy in December 1988

European University Institute

Badia Fiesolana

- 50016 San Domenico (FI) -

Italy 
THE THREE POLITICAL ECONOMIES OF THE WELFARE STATE

by

Gösta Esping-Andersen

European University Institute

Florence

This is part of an ongoing project on welfare states and labor markets, funded by the Research Council of the IUE and European Community. I wish to thank Thomas Cusack, Steven Lukes, John Myles, Fritz von Nordheim Nielsen, and the participants in my IUE seminar on Political Economy, for their constructive comments and criticisms on an earlier version of this paper. 

The protracted debate on the welfare state has failed to produce conclusive answers as to either the nature or causes of welfare state development. This article has three aims: 1) to reintegrate the debate into the intellectual tradition of political economy. This serves to put into sharper focus the principal theoretical questions involved; 2) to specify what are the salient characteristics of welfare states. The conventional ways of measuring welfare states in terms of their expenditures will no longer do; 3) to "sociologize" the study of welfare states. Most studies have assumed a world of linearity: more or less power, industrialization or spending. This article insists that we understand welfare states as clusters of regime-types, and that their development must be explained interactively.

THE LEGACY OF CLASSICAL POLITICAL ECONOMY

Contemporary welfare state debates have been guided by two questions. First, does social citizenship diminish the salience of class? Or, in other words, can the welfare state fundamentally transform capitalist society? second, what are the causal forces behind welfare state development? These questions are not recent. Indeed, they were formulated by the 19th Century political economists 100 years before any welfare state can rightfully be said to have come into existence. The classical political economists -- whether of liberal, conservative or Marxist persuasion --were pre-occupied with the relationship between capitalism and welfare. Their answers obviously diverged, but their analyses were unequivocally directed to the relationship between market (and property), and 
the state (democracy). The question they asked was largely normative: what is the optimal division of responsibility between market and state?

Contemporary neo-liberalism echoes the contributions of classical liberal political economy. To Adam Smith, the market was the superior means for the abolition of class, inequality and privilege. Aside from a necessary minimum, state intervention would likely stifle the equalizing process of competitive exchange, create monopolies, protectionism and inefficiency: the state upholds class, the market can potentially undo class society (Smith, 1961: I I, especially pp.232-6). 1

Liberal political economists were not necessarily of one mind when it came to policy advocacy. Nassau Senior and later Manchester liberals emphasized the laissezfaire element of Smith, rejecting any form of social protection outside the cash nexus. J.S.Mill and the "reformed liberals", in turn, were willing to let markets be regulated by a modicum of political regulation. Yet, they were all agreed that the road to equality and prosperity should be paved with a maximum of free markets and a minimum of state interference.

This enthusiastic embrace of market capitalism may now appear unjustified. But, we must take into account that the state which confronted these early political economists was tinged with legacies of absolutist privileges, mercantilist protectionisms, and pervasive corruption. They were attacking systems of governance which repressed the ideals of both freedom and enterprise. Hence, theirs was revolutionary theory, and from this vantage point, we can understand why Adam Smith sometimes reads 1 ike Karl Marx. $x^{2}$ 
Democracy was an Achilles heel to many liberals. Their ideals of freedom and democratic participation were grounded in a world of small property owners; not of growing property-less masses who held in their sheer numbers the possibility of seizing state power. The 1 iberals feared the principle of universal suffrage, for it would likely politicize the distributional struggle, pervert the market and fuel inefficiencies. Many liberals discovered that democracy would contradict the market.

Both conservative and Marxist political economists understood this contradiction, but proposed of course opposite solutions. The most coherent conservative critique of laissez faire came from the German historical school; in particular from Friedrich List, Adolph wagner and Gustav Schmoller. They refused to believe that capitalist efficiency was best assured by the pure commodity status of workers in the raw cash nexus of the market. Instead, conservative political economy believed that patriarchical neo-absolutism could provide the kind of legal, political and social framework that would assure a capitalism without class struggle.

One prominent conservative school promoted a "Monarchical Welfare State" that would, at once, provide for social welfare, class harmony, loyalty, and productivity. It was discipline, not competition, that would guarantee efficiency. The state (or church) was the institution best equipped to harmonize conflicting interests. $s$

Conservative political economy emerged in reaction to the French Revolution and the Paris Commune. It was avowedly nationalist, anti-revolutionary, and sought to 
arrest the democratic impulse. It feared social leveliing, and favored a society that retained both hierarchy and class. It held that class conflicts were not natural; that democratic mass participation, the dissolution of recognized rank and status boundaries were threats to social harmony.

The key to Marxian political economy, of course, was its rejection of the liberal claim that markets guarantee equality. Capitalist accumulation, as Dobb (1946) put it, disowns people of property with the endresult being ever deeper class divisions. Here, the state's role is not neutrally benevolent, nor is it a fountain of emancipation; it exists to defend property rights and the authority of capital. To Marxism this is the foundation of class dominance.

The central question, not only for Marxism but for the entire contemporary debate on the welfare state, is whether and under what conditions the class divisions and social inequalities produced by capitalism can be undone by parliamentary democracy. The liberals feared that democracy would produce socialism and they were consequently not especially eager to extend it. The socialists, in contrast, suspected that parliamentarism would be little more than an empty shell or, as Lenin suggested, a mere "talking shop" (Jessop, 1982). This line of analysis, echoed in much of contemporary Marxism, leads to the conclusion that social reforms emerge in response to the exigencies of capitalist reproduction, not to the emancipatory desires of the working classes. 4

Among socialists, a more positive analysis of parliamentarism came to prevail after the extension of full political citizenship. The theoretically most 
sophisticated contributions came from Austro-Marxists such as Adler and Bauer, and from German social democrats, especially Eduard Heimann. Heimann's (1929) starting point was that even conservative reforms may have been motivated by desires to repress labor mobilization, but that their very presence nonetheless alter the balance of class power: the social wage lessens the worker's dependence on the market and employers. The social wage is thus also a potential power resource that defines the frontier between capitalism and socialism. It introduces an alien element into the capitalist political economy. This intellectual position has enjoyed quite a renaissance in recent Marxism (Offe,1985; Bowles and Gintis, 1986).

The social democratic model, as out ined above, did not necessarily abandon the orthodox assumption that fundamental equality requires economic socialization. Yet, historical experience soon demonstrated that socialization was a goal that could not be pursued realistically through parliamentarism."

Social democracy's embrace of parliamentary reformism as its dominant strategy for equality and socialism was premised on two arguments. The first was that workers require social resources, health and education to participate effectively in a democratized economy. The second argument was that social policy is not only emancipatory, but it is also economically efficient (Myrdal \& Myrdal, 1936). Following Marx on this point, the strategy therefore promotes the onward march of capitalist productive forces. But, the beauty of the strategy was that social policy would also assure social democratic power mobilization. By eradicating poverty, unemployment and complete wage dependency, the welfare 
state increases political capacities and diminishes the social divisions that are barriers to political unity among workers.

The social democratic model, then, puts forward one of the leading hypotheses of contemporary welfare state debate: the argument that parliamentary class mobilization is a means for the realization of socialist ideals of equality, justice, freedom and solidarity.

THE POLITICAL ECONOMY OF THE WELFARE STATE

Our political economy forebears defined the analytic basis of much recent scholarship. They isolated the key variables of class, state, market and democracy; and they formulated the basic propositions about citizenship and class, efficiency and equality, capitalism and socialism. Contemporary social science distinguishes itself from classical political economy on two scientifically vital fronts. First, it defines itself as a positive science and shies away from normative prescription (Robbins, 1976). Second, classical political economists had little interest in historical variability; they saw their efforts as leading towards a system of universal laws. Although contemporary political economy sometimes still clings to the belief in absolute truths, the comparative and historical method that, today, underpins almost all good political economy is one that reveals variation and permeability.

Despite these differences, most recent scholarship has as its focal point the state-economy relationship defined by $19 \mathrm{th}$ Century political economists. And, given its enormous growth, it is understandable that the 
welfare state has become a major test case for contending theories of political economy.

Below, we shall review the contributions of comparative research on the development of welfare states in advanced capitalist countries. It will be argued that most scholarship has been misdirected, mainly because it became detached from its theoretical foundations. We must therefore recast both the methodology and concepts of political economy in order to adequately study the welfare state. This will constitute the focus of the final section of this paper.

Two types of approaches have dominated in the explanation of welfare states; one, a systemic (or, structuralist) theory; the other, an institutional or actor-oriented explanation.

THE SYSTEMS/STRUCTURALIST APPROACH

System- or structuralist theory seeks to capture the logic of development holistically. It will easily focus on the functional requisites for the reproduction of society and economy; it will be inclined to emphasize cross-national similarities rather than differences.

One variant begins with a theory of the industrial society, and argues that industrialization makes social policy both necessary and possible. It makes welfare states necessary because pre-industrial modes of social reproduction, such as the family, the church, noblesse oblige, and guild solidarity are destroyed by the forces attached to modernization -- social mobility, urbanization, individualism, and market dependence. The 
crux of the matter is that the market is no adequate substitute because it caters only to those who are able to perform in it. Hence, the "welfare function" is appropriated by the nation state. The welfare state is also made possible by the rise of modern bureaucracy as a rational, universalist and efficient form of organization. It is a means for managing collective goods, but also a center of power in its own right, and will thus be inclined to promote its own growth.

This kind of reasoning has informed the so-called "logic of industrialism" perspective, according to which the welfare state will emerge as the modern industrial economy destroys traditional forms of social security (Flora and Alber, 1981; Pryor, 1969). But, the thesis has difficulties explaining why government social policy only emerged 50 or even 100 years after traditional community was effectively destroyed? The basic response draws on Wagner's Law $(1962 ; 1883$ ) and on Marshall (1920), namely that a certain level of economic development, and thus surplus, is needed in order to permit the diversion of scarce resources from productive use (investments) to welfare (wilensky and Lebeaux, 1958). In this sense, the perspective follows in the footsteps of the old 1 iberals. Social redistribution endangers efficiency, and only at a certain economic level will a negative-sum trade-off be avoidable (Okun, 1975).

The new structural Marxism offers a surprisingly parallel analysis. It breaks with its classical forebears' strongly action-centered theory. Like the industrialism thesis, its analytical starting point is not the problems of markets, but the logic of a mode of production. Capital accumulation creates contradictions that social reform can alleviate (O'Connor, 1973). This 
tradition of Marxism, like its "logic of industrialism" counterpart, fails to see much relevance of actors in the promotion of welfare states. The point is that the state, as such, is positioned in such a way that it will serve the collective needs of capital. The theory is thus premised on two crucial assumptions: first, that power is structural and second, that the state is "relatively" autonomous from class directives (Poulantzas, 1973; Block, 1977; for a recent critical assessment of this literature, see Therborn, 1986; and Skocpol and Amenta, 1986).

The "logic of capitalism" perspective invites difficult questions. If, as Przworski (1980) has argued, working class consent is assured on the basis of material hegemony, that is self-willed subordination to the system, it is difficult to see why up to 40 per cent of the national product must be allocated to the legitimation activities of a welfare state. A second problem is to derive state activities from a "mode of production" analysis. Eastern Europe may perhaps not qualify as socialist, but neither is it capitalist. Yet, there we find "welfare states", too. Perhaps accumulation has functional requirements in whichever way it proceeds? (Skocpol and Amenta, 1986; Bell, 1978).

THE INSTITUTIONAL APPROACH

The classical political economists made it clear why democratic institutions should influence welfare state development. The liberals feared that full democracy might jeopardize markets and inaugurate socialism. Freedom, in their view, necessitated a defence of markets against political intrusion. In practice, this is what 
the laissez-faire state sought to accomplish. But it was this divorce of politics and economy which fuelled much of the institutionalist analyses. Best represented by Polanyi (1944), but also by a number of anti-democratic exponents of the historical school, the institutional approach insists that any effort to isolate the economy from social and political institutions will destroy human society. The economy must be embedded in social communities in order for it to survive. Thus, Polanyi sees social policy as one necessary precondition for the re-integration of the social economy.

An interesting recent variant of institutional alignment theory is the argument that welfare states emerge more readily in small, open economies that are particularly vulnerable to international markets. As Katzenstein (1985) and Cameron (1978) show, there is a greater inclination to regulate class distributional conflicts through government and interest concertation when both business and labor are captive to forces beyond domestic control.

The impact of democracy on welfare states has been argued ever since J.S. Mill and de Tocqueville. The argument is typically phrased without reference to any particular social agent or class. It is, in this sense, that it is institutional. In its classical formulation, the thesis was simply that majorities will favor social distribution to compensate for market weakness or market risks. If wage earners are likely to demand a social wage, so are capitalists (or farmers) apt to demand protection in the form of tariffs, monopoly or subsidies. Democracy is an institution that cannot resist majoritarian demands. 
In its modern formulations, the democracy thesis has many variants. One identifies stages of nationbuilding in which full citizenship incorporation requires social rights (Marshal1,1950; Bendix, 1964; Rokkan, 1970). A second variant, developed by both pluralist and public choice theory, argues that democracy will nurture intense party competition around the median voter that will, in turn, fuel rising public expenditures. Tufte (1978), for example, argues that major extensions of public intervention will occur around elections as a means of voter mobilization.

The democratic-institutionalist approach faces considerable empirical problems (Skocpol and Amenta, 1986). According to the thesis, a democratic polity is the basic precondition for welfare state emergence, and welfare states are more likely to develop the more democratic rights are extended. Yet, the thesis confronts not only the historical oddity that the first major welfare state initiatives occurred prior to democracy, but also that they were often motivated by desires to arrest its realization. This was certainly the case in France under Napoleon II, in Germany under Bismarck, and in Austria under Taaffe. Conversely, welfare state development was most retarded where democracy arrived early, such as in the United States, Australia, and Switzerland. This apparent contradiction can be explained, but only with reference to social classes and social structure: nations with early democracy were overwhelmingly agrarian and dominated by small property owners who used their electoral powers to reduce, not raise, taxes (Dich, 1973). In contrast, ruling classes in authoritarian polities are better positioned to impose high taxes on an unwilling populace. 
SOCIAL CLASS AS A POLITICAL AGENT

We have noted that the case for a class mobilization thesis flows from social democratic political economy. It differs from structuralist and institutional analyses by its emphasis on the social classes as the main agents of change, and its argument that the balance of class power determines distributional outcomes. To emphasize active class mobilization does not necessarily deny the importance of structured or hegemonic power (Korpi, 1983). But it is held that parliaments are, in principle, effective institutions for the translation of mobilized power into desired policies and reforms. Accordingly, parliamentary politics are capable of overriding hegemony, and may be made to serve interests that are antagonistic to capital. Further, the class mobilization theory assumes that welfare states do more than simply alleviate the current ills of the system; a "social democratic" welfare state will, in its own right, establish critical power resources for wage earners and, thus, strengthen labor movements. As Heimann (1929) originally held, social rights push back the frontiers of capitalist power and prerogatives.

The question of why the welfare state itself is a power resource is vital for the theory's applicability. The answer is that wage earners in the market are inherently atomized and stratified, compelled to compete, insecure and dependent on decisions and forces beyond their control. This limits their capacity for collective solidarity and mobilization. The social rights, income security, equalization and eradication of poverty that a universalistic welfare state pursues, are necessary preconditions for the strength and unity that collective 
power mobilization demands (Esping-Andersen, 1985a).

The single most difficult problem for this thesis is to specify the conditions for power mobilization. Power depends on the resources that flow from the unity of electoral numbers and from collective bargaining. Power mobilization, in turn, depends on levels of trade union organization, vote shares, parliamentary- and cabinet seats held by left, or labor, parties. But how long a period of sustained power mobilization is required in order to produce decisive effects? If power is measured over a brief time span (5-10 years), we risk the fallacy of a "Blum"/"Mitterand" effect: a brief spell of leftist power that proves ineffectual because the left is ousted again before having had a chance to act.

There are several valid objections to the class mobilization thesis. Three, in particular, are quite fundamental. One, is that in advanced capitalist nations, the locus of decision making and power may shift from parliaments to neo-corporatist institutions of interest intermediation (Shonfield, 1965; Schmitter and Lembruch, 1979). A second criticism is that the capacity of labor parties to influence welfare state development is circumscribed by the structure of rightist party power. Castles (1978; 1982) has argued that the degree of unity among the rightist parties is more important than is the activated power of the left. Other authors have emphasized the fact that denominational (usually social catholic) parties in countries such as Holland, Italy, and Germany mobilize large sections of the working classes and pursue welfare state programs not drastically at variance with their socialist competitors (Schmidt, 1982; Wilensky, 1981). The class mobilization thesis has, rightly, been criticized for its swedocentrism, i.e. its 
inclination to define the process of power mobilization too much on the basis of the rather extraordinary Swedish experience (Shalev, 1984).

These objections address a basic fallacy in the theory's assumptions about class formation: we cannot assume that socialism is the natural basis for wageearner mobilization. Indeed, the conditions under which workers become socialists are still not adequately documented. Historically, the natural organizational bases of worker mobilization were pre-capitalist communities, especially the guilds, but also the Church, ethnicity or language. A ready-made reference to false consciousness will not do to explain why Dutch, Italian or American workers continue to mobilize around nonsocialist principles. The dominance of socialism in the Swedish working class is as much a puzzle as is the dominance of confessionalism in the Dutch.

The third and, perhaps, most fundamental objection has to do with the model's linear view of power. It is problematic to hold that a numerical increase in votes, unionization or seats will translate into more welfare statism. First, for socialist as for other parties, the magical "50 per cent" threshold for parliamentary majorities seems practically unsurmountable (Przworski, 1985). Second, if socialist parties represent working classes in the traditional sense, it is clear that they will never succeed in their project. In very few cases has the traditional working class been numerically a majority; and its role is rapidly becoming marginal.o

Probably the most promising way to resolve the combined linearity- and working class minority problem lies in recent applications of Barrington Moore's path- 
breaking class coalition thesis to the transformation of the modern state (Weir and Skocpol, 1985; Gourevitch, 1986; Esping-Andersen, 1985a; Esping-Andersen \& Friedland, 1982). Thus, the origins of the keynesian full employment commitment and the social democratic welfare state edifice have been traced to the capacity of (variably) strong working class movements to forge a political alliance with farmers organizations; additionally, it is arguable that sustained social democracy has come to depend on the formation of a new working class-white collar coalition.

The class coalitional approach has additional virtues. Two nations, such as Austria and Sweden, may score similarly on working class mobilization variables, and yet produce highly unequal policy results. This can be explained by differences in the two countries' historical coalition formation: the breakthrough of Swedish social democratic hegemony stems from its capacity to forge the famous "red-green" alliance; the comparative disadvantage of the Austrian socialists rests in the "ghetto" status assigned to them by virtue of the rural classes being captured by a conservative coalition (Esping-Andersen and Korpi, 1984).

In sum, we have to think in terms of social relations, not just social categories. Whereas structural-functionalist explanations identify convergent welfare state outcomes, and class mobilization paradigms see large, but linearly distributed, differences, an interactive model such as the coalitions approach directs attention to distinct welfare state regimes

WHAT IS THE WELFARE STATE ?

Every theoretical paradigm must somehow define the 
welfare state. How do we know when and if a welfare state responds functionally to the needs of industrialism, or to capitalist reproduction and legitimacy? And how do we identify a welfare state that corresponds to the demands that a mobilized working class might have? We cannot test contending arguments unless we have a commonly shared conception of the phenomenon to be explained.

A remarkable attribute of the entire literature is its lack of much genuine interest in the welfare state as such. Welfare state studies have been motivated by theoretical concerns with other phenomena, such as power, industrialization or capitalist contradictions; the welfare state itself has generally received scant conceptual attention. If welfare states differ, how do they differ? And when, indeed, is a state a welfare state? This turns attention straight back to the original question: what is the welfare state?

A common textbook definition is that it involves state responsibility for securing some basic modicum of welfare for its citizens. Such a definition skirts the issue of whether social policies are emancipatory or not; whether they help system legitimation or not; whether they contradict or aid the market process; and what, indeed, is meant by "basic"? Would it not be more appropriate to require of a welfare state that it satisfies more than our basic or minimal welfare needs?

The first generation of comparative studies started with this type of conceptualization. They assumed, without much reflection, that the level of social expenditure adequately reflects a state's commitment to welfare. The theoretical intent was not really to arrive at an understanding of the welfare state, but rather to 
test the validity of contending theoretical models in political economy. By scoring nations with respect to urbanization, level of economic growth, and the share of aged in the demographic structure, it was believed that the essential features of industrial modernization were adequately captured. Alternatively, by scoring nations on left party strength, or working class power mobilization (with complex weighted scores of trade unionism, electoral strength and cabinet power), others sought to identify the impact of working class mobilization as formulated in the social democratic model.

The findings of the first generation comparativists are extremely difficult to evaluate. No convincing case can be made for any particular theory. The shortage of nations for comparisons statistically restricts the number of variables that can be tested simultaneously. Thus, when Cutright (1965) or Wilensky (1975) finds that economic level, with its demographic and bureaucratic correlates, explains most welfare state variations in "rich countries", relevant measures of working class mobilization or economic openness are not included. A conclusion in favor of a "logic of industrialism" view is therefore in doubt. And, when Hewitt (1977), Stephens (1979), Korpi (1983), Myles (1984) and Esping-Andersen (1985b) find strong evidence in favor of a working class mobilization thesis, or when Schmidt (1982;1983) finds support for a neo-corporatist, and Cameron (1978) for an economic openness argument, it is without fully testing against the strongest alternative explanation.?

Most of these studies claim to explain the welfare state. Yet, their focus on spending may be irrelevant or, at best, misleading. Expenditures are epiphenomenal to the theoretical substance of welfare states. Moreover, 
the linear scoring approach (more or less power, democracy or spending) contradicts the sociological notion that power, democracy, or welfare are relational and structured phenomena. By scoring welfare states on spending, we assume that all spending counts equally. But, some welfare states, the Austrian for example, spend a large share on benefits to privileged civil servants. This is normally not what we would consider a commitment to social citizenship and solidarity. Others spend disproportionally on means-tested social assistance. Few contemporary analysts would agree that a reformed poor relief tradition qualifies as a welfare state commitment. Some nations spend enormous sums on fiscal welfare in the form of tax privileges to private insurance plans that mainly benefit the middle classes. But these tax expenditures do not show up on expenditure accounts. In Britain, total social expenditure has grown during the Thatcher period; yet, this is almost exclusively a function of very high unemployment. Low expenditures on some programs may signify a welfare state more seriously committed to full employment.

Therborn (1983) is right when he holds that we must begin with a conception of state structure. What are the criteria with which we should judge whether, and when, a state is a welfare state? There are three approaches to this question. Therborn's proposal is to begin with the historical transformation of state activities. Minimally, in a genuine welfare state the majority of its daily routine activities must be devoted to servicing the welfare needs of households. This criterion has farreaching consequences. If we simply measure routine activity in terms of spending and personnel, the result is that no state can be regarded as real welfare state until the 1970's! And, some that we normally label as 
welfare states will still not qualify because the majority of their routine activities concern defence, law and order, administration and the like (Therborn, 1983). Social scientists have been too quick to accept nations' self-proclaimed welfare state status. They have also been too quick to conclude that the presence of the battery of typical social programs signify the birth of a welfare state.

The second conceptual approach derives from Richard Titmuss' (1958) classical distinction between residual and institutional welfare states. The former assumes that state responsibility begins only when the family or the market fails; its commitment is limited to marginal groups in society. The latter model addresses the entire population, is universalistic, and implants an institutionalized commitment to welfare. It will, in principle, extend welfare commitments to all areas of distribution vital for societal welfare. This approach has fertilized a variety of new developments in comparative welfare state research (Myles, 1984; Korpi, 1980; Esping-Andersen and Korpi, 1984;1986; EspingAndersen, 1985b; 1987). And it has forced researchers to move away from the black box of expenditures and towards the content of welfare states: targeted versus universalistic programs, the conditions of eligibility, the quality of benefits and services and, perhaps most importantly, the extent to which employment and working life are encompassed in the state's extension of citizen rights. This shift to welfare state typologies makes simple linear welfare state rankings difficult to sustain. We might in fact be comparing categorically different types of states.

The third approach is to select theoretically the 
criteria on which to judge types of welfare states. This can be done by measuring actual welfare states against some abstract model and then by scoring programs, or entire welfare states, accordingly (Day, 1978; Myles, 1984). The weakness of this approach is that it is ahistorical, and does not necessarily capture the ideals or designs that historical actors sought to realize in the struggles over the welfare state. If our aim is to test causal theories that involve actors, we should begin with the demands that were actually promoted by those actors that we deem critical in the history of welfare state development. It is difficult to imagine that anyone struggled for spending per se.

\section{A RESPECIFICATION OF THE WELFARE STATE}

Few can disagree with T.H. Marshall's (1950) proposition that social citizenship constitutes the core idea of a welfare state. What, then, are the key principles involved in social citizenship? In our view, they must involve first and foremost the granting of social rights. This mainly entails a de-commodification of the status of individuals vis-a-vis the market. Secondly, social citizenship involves social stratification; one's status as a citizen will compete with, or even replace, one's class position. Thirdly, the welfare state must be understood in terms of the interface between the market, the family, and the state. These principles need to be fleshed out prior to any theoretical specification of the welfare state. 
Rights and De-Commodification

As commodities in the market, workers depend for their welfare entirely on the cash-nexus. The question of social rights is thus one of de-commodification, that is of granting alternative means of welfare to that of the market. De-commodification may refer either to the service rendered, or to the status of a person, but in both cases it signifies the degree to which distribution is detached from the market mechanism. This means that the mere presence of social assistance or insurance may not necessarily bring about significant decommodification if they do not substantially emancipate individuals from market dependence. Means-tested poor relief will possibly offer a security blanket of last resort. But if benefits are low and attached with social stigma, the relief system will compel all but the most desperate to participate in the market. This was precisely the intent of the 19th century poor laws. Similarly, most of the early social insurance programs were deliberately designed to maximize labor market performance (Ogus, 1979). Benefits required long contribution periods and were tailored to prior work effort. In either case, the motive was to avert workdisincentive effects.

There is no doubt that de-commodification has been a hugely contested issue in welfare state development. For labor, it has always been a priority. When workers are completely market dependent, they are difficult to mobilize for solidaristic action. Since their resources mirror market inequalities, divisions emerge between the "ins" and the "outs", making labor movement formation difficult. De-commodification strengthens the worker and 
weakens the absolute authority of the employer. It is for exactly this reason that employers always opposed decommodification.

De-commodified rights are differentially developed in contemporary welfare states. In social assistance dominated welfare states rights are not so much attached to work performance as to demonstrable need. Needs-tests and typically meager benefits, however, serve to curtail the de-commodifying effect. Thus, in nations where this model is dominant (mainly in the Anglo-Saxon countries), the result is actually to strengthen the market since all but those who fail in the market will be encouraged to contract private sector welfare.

A second dominant model espouses compulsory state social insurance with fairly strong entitlements. Yet, again, this may not automatically secure substantial decommodification, since this hinges very much on the fabric of eligibility and benefit rules. Germany was the pioneer of social insurance, but over most of the century can hardly be said to have brought about much in the way of de-commodification through its social programs. Benefits have depended almost entirely on contributions and, thus, work and employment. In fact, before the second world war, average pensions in the German insurance system for workers were lower than prevailing poverty assistance rates (Myles, 1984). The consequence, as with the social assistance model, was that most workers would chose to remain at work rather than retire. In other words, it is not the mere presence of a social right, but the corresponding rules and preconditions that dictate the extent to which welfare programs offer genuine alternatives to market dependence. 
The third dominant model of welfare, namely the Beveridge-type citizens benefit, may, at first glance, appear the most de-commodifying. It offers a basic, equal benefit to all irrespective of prior earnings, contributions or performance. It may indeed be a more solidaristic system, but not necessarily de-commodifying since, only rarely, have such schemes been able to offer benefits of such a standard that they provide recipients with a genuine option to that of working.

De-commodifying welfare states are, in practice, of very recent date. A minimalist definition must entail that citizens can freely, and without potential losses of job, income or general welfare, opt out of work under conditions when they, themselves, consider it necessary for reasons of health, family, age or even educational self-improvement; when, in short, they deem it necessary for participating adequately in the social community.

With this definition in mind, we would, for example, require of a sickness insurance that individuals be secured benefits equal to normal earnings, the right to absence with minimal proof of medical impairment, and for the duration that the individual deems necessary. These conditions, it is worth noting, are those usually enjoyed by academics, civil servants and higher echelon white collar employees. Similar requirements would be made of pensions, maternity leave, parental leave, educational leave and unemployment insurance.

Some nations have moved towards this level of decommodification, but only recently and, in many cases, with significant exemptions. Thus, in almost all nations benefits were upgraded to almost equal normal wages in the late 1960s and early 1970s. But, in some countries for example, prompt medical certification in case of 
illness is still required; in others, entitlements depend on long waiting periods of up to two weeks; and, in still others, the duration of entitlements is very short (in the United States, for example, unemployment benefit duration is maximally six months, compared to 30 in Denmark). Overal1, the Scandinavian welfare states tend to be the most de-commodifying; the Anglo-Saxon the least.

The Welfare State as a System of Stratification

Despite the emphasis given to it in both classical political economy and in T.H.Marshall's pioneering work, the relationship between citizenship and social class remains severely neglected, both theoretically and empirically. Generally speaking, the issue has either been assumed away (it has been taken for granted that the welfare state creates a more egalitarian society), or it has been approached narrowly in terms of income distribution or in terms of whether education promotes upward social mobility. A more basic question, it seems, is what kind of stratification system is promoted by social policy. The welfare state is not just a mechanism that intervenes in, and possibly corrects, the structure of inequality; it is, in its own right, a system of stratification. It orders actively and directly social relations.

Comparatively and historically, we can easily identify alternative systems of stratification embedded in welfare states. The poor relief tradition, and its contemporary means-tested social assistance offshoot, was conspicuously designed for purposes of stratification. By punishing and stigmatizing recipients, it promotes severe 
social dualisms, especially within the ranks of the working classes. It comes as no surprise that this model of welfare has been a chief target of labor movement attacks.

The social insurance model promoted by conservative reformers such as Bismarck and von Taaffe was also explicitly a form of class politics. It sought, in fact, to achieve two simultaneous stratification results. The first was to consolidate divisions among wage earners by legislating distinct programs for different class and status groups, each with its own conspicuously unique set of rights and privileges designed to accentuate the individual's appropriate station in life. The second objective was to tie the loyalties of the individual directly to the monarchy, or central state authority. This was Bismarck's motive when he promoted a direct state supplement to the pension benefit. This statecorporativist model was pursued mainly in nations such as Germany, Austria, Italy and France and often resulted in a labyrinth of status-specific insurance funds (in France and Italy, for example, there exist more than 100 statusdistinct pension schemes).

Of special importance in this corporatist tradition was the establishment of particularly privileged welfare provisions for the civil service ("Beamten"). In part, this was a means of rewarding loyalty to the state and in part, a way of demarcating this group's uniquely exalted social status. We should, however, be careful to note that the corporatist status-differentiated model springs mainly from the old guild tradition. The neo-absolutist autocrats, such as Bismarck, saw in this tradition a means to combat the rising labor movements. 
The labor movements were as hostile to the corporatist model as they were to poor relief-- in both cases for obvious reasons. Yet, the alternatives first espoused by labor were no less problematic from the point of view of uniting the workers as one solidaristic class. Almost invariably, the model that labor first pursued was that of the self-organized friendly societies or equivalent union- or party-sponsored fraternal welfare plan. This is not surprising. Workers were obviously suspicious of reforms sponsored by a hostile state, and saw their own organizations not only as bases of class mobilization, but also as embryos of an alternative world of solidarity and justice, as a microcosm of the socialist haven to come. Nonetheless, these microsocialist societies often became problematic class ghettos that divided rather than united workers. Membership was typically restricted to the strongest strata of the working class and the weakest --who needed protection most -- were most likely outside. In brief, the fraternal society model contradicted the goal of working class mobilization.

The socialist ghetto approach was an additional obstacle when socialist parties found themselves forming governments and having to pass the social reforms they so long had demanded. For reasons of political coalition building and broader solidarity, their welfare model had to be recast as welfare for the "people". Hence, the socialists came to espouse the principle of universalism and, borrowing from the liberals, typically designed on the lines of the democratic flat-rate, general revenue financed, Beveridge model.

As an alternative to means-tested assistance and corporatist social insurance, the universalistic system 
promotes status equality. All citizens are endowed with similar rights, irrespective of class or market position. In this sense, the system is meant to cultivate crossclass solidarity, a solidarity of the nation. But, the solidarity of flat-rate universalism presumes an nistorically peculiar class structure; one in which the vast majority of the population are the "little people" for whom a modest, albeit egalitarian, benefit may be considered adequate. Where this no longer obtains, as occurs with growing working class prosperity and the rise of the new middle classes, flat-rate universalism inadvertently promotes dualism because the better off turn to private insurance and to fringe-benefit bargaining to supplement modest equality with what they have decided are accustomed standards of welfare. Where this process unfolds (as in Canada or the United Kingdom), the result is that the wonderfully egalitarian spirit of universalism turns into a dualism similar to that of the social assistance state: the poor rely on the state, and the remainder on the market.

It is not only the universalist, but in fact all historical welfare state models which have faced the dilemma of class structural change. But, the response to prosperity and middle class growth has been varied and so, therefore, has been the stratificational outcome. The corporatist insurance tradition was, in a sense, best equipped to manage new and loftier welfare state expectations since the existing system could technically be upgraded quite easily to distribute more adequate benefits. Adenauer's 1957 pension reform in Germany was a pioneer in this respect. Its avowed purpose was to restore status differences that had eroded due to the old insurance system's incapacity to provide benefits tailored to expectations. This it did simply by moving 
from contribution- to earnings-graduated benefits without altering the framework of status-distinctiveness.

In nations with either a social assistance or a universalistic Beveridge-type system, the option was whether to allow the market or the state to furnish adequacy and satisfy middle class aspirations. Two alternative models emerged from this political choice. The one typical of Great Britain and most of the Anglo Saxon world was to preserve an essentially modest universalism in the state and allow the market to reign for the growing social strata demanding superior welfare. Due to the political power of such groups, the dualism that emerges is not merely one between state and market, but also between forms of welfare state transfers: in these nations, one of the fastest growing components of public expenditure is tax-subsidies for so-called "private" welfare plans. And the typical political effect is eroding middle class support for what is less and less a universalistic public sector transfer system.

Yet another alternative has been to seek a synthesis of universalism and adequacy outside of the market. This road has been followed in the countries where, by mandating or legislation, the state includes the new middle classes by erecting a luxurious second-tier, universally inclusive, earnings related insurance scheme on top of the flat-rate egalitarian one. Notable examples are Sweden and Norway. By guaranteeing benefits tailored to expectations, this solution re-introduces benefit inequalities, but effectively blocks off the market. It thus succeeds in retaining universalism and, therefore, also the degree of political consensus required to preserve broad and solidaristic support for the high taxes that such a welfare state model demands. 


\section{Welfare State Regimes}

Welfare states vary considerably with respect to their principles of rights and stratification. This results in qualitatively different arrangements between state, market and the family. The welfare state variations we find, are therefore, not linearly distributed, but clustered by regime-types.

In one cluster, we find the "liberal" welfare state, in which means-tested assistance, modest universal transfers, or modest social insurance plans predominate. These cater mainly to a clientele of low income, usually working class, state dependents. It is a model in which, implicitly or explicitly, the progress of social reform has been severely circumscribed by traditional, liberal work-ethic norms; one where the limits of welfare equal the marginal propensity to demand welfare instead of work. Entitlement rules are therefore strict and often associated with stigma; benefits are typically modest. In turn, the state encourages the market, either passively by guaranteeing only a minimum, or actively by subsidizing private welfare schemes.

The consequence is that this welfare state regime minimizes de-commodification-effects, effectively contains the realm of social rights, and erects a stratification order that blends a relative equality of poverty among state welfare recipients, marketdifferentiated welfare among the majorities, and a classpolitical dualism between the two. The archetypical examples of this model are the United States, Canada, and Australia. Nations that approximate the model are Denmark, Switzerland, and Great Britain. 
A second regime-cluster is composed of nations such as Austria, France, Germany and Italy. Here, the historical corporatist-statist legacy was upgraded to cater to the new "post-industrial" class structure. In these "corporativist" welfare states, the liberal obsession with market efficiency and commodification was never pre-eminent and, as such, the granting of social rights was hardly ever a seriously contested issue. What predominated was the preservation of status differentials; rights, therefore, were attached to class and status. This corporativism was subsumed under a state edifice perfectly ready to displace the market as a provider of welfare; hence, private insurance and occupational fringe benefits play a truly marginal role in this model. On the other hand, the state's emphasis on upholding status differences means that its redistributive effects are negligible.

But, the corporativist regimes are also typically shaped by the Church, and therefore influenced by a strong commitment to the preservation of traditional family patterns. Social insurance typically excludes nonworking wives, and family benefits encourage motherhood. Day care, and similar family services, are conspicuously underdeveloped, and the "subsidiarity principle" serves to emphasize that the state will only interfere when the family's capacity to service its members is exhausted. An illustrative example is German unemployment assistance. once a person has exhausted his/her entitlement to normal unemployment insurance, eligibility for continued assistance depends on whether one's family commands the financial capacity to aid the unfortunate; this obtains for persons of any age. 
The third, and clearly smallest, regime-cluster is composed of those countries in which the principles of universalism and de-commodifying social rights were extended also to the new middle classes. We may call it the "social democratic" regime-type since, in these nations, social democracy clearly was the dominant force behind social reform. Norway and sweden are the clearest cases, but we should also consider Denmark and Finland. Rather than tolerate a dualism between state and market, between working class and middle class, the social democrats pursued a welfare state that would promote an equality of the highest standards, rather than an equality of minimal needs as was pursued elsewhere. This implied, first, that services and benefits be upgraded to levels commensurable to even the most discriminate tastes of the new middle classes; and, secondly, that equality be furnished by guaranteeing workers full participation in the quality of rights enjoyed by the better off.

This formula translates into a mix of highly decommodifying and universalistic programs that, nonetheless, are tailored to differentiated expectations. Thus, manual workers come to enjoy rights identical to those of salaried white collar employees or civil servants; all strata and classes are incorporated under one universal insurance system; yet, benefits are graduated according to accustomed earnings. This model crowds out the market and, consequently, inculcates an essentially universal solidarity behind the welfare state. All benefit, all are dependent, and all will presumably feel obliged to pay.

The social democratic regime's policy of emancipation addresses both the market and the traditional family. In contrast to the corporatist-subsidiarity 
model, the principle is not to wait until the family's capacity to aid is exhausted, but to pre-emptively socialize the costs of familyhood. The ideal is not to maximize dependence on the family, but capacities for individual independence. In this sense, the model is a peculiar fusion of 1 iberalism and socialism. The result is a welfare state that grants transfers directly to the children, and takes direct caring responsibilities for children, the aged and the helpless. It is, accordingly, committed to a heavy social service burden, not only to service family needs, but also to permit women to chose work rather than the household.

Perhaps the most salient characteristic of the social democratic regime is its fusion of welfare and work. It is, at once, a welfare state genuinely committed to a full employment guarantee, and a welfare state entirely dependent on its attalnment. On the one side, it is a model in which the right to work has equal status to the right of income protection. On the other side, the enormous costs of maintaining a solidaristic, universalistic and de-commodifying welfare system means that it must minimize social problems and maximize revenue income. This is obviously best done with most people working, and the fewest possible living off social transfers.

While it is empirically clear that welfare states cluster, we must recognize that no single case is pure. The social democratic regimes of Scandinavia blend crucial socialist and liberal elements. The Danish and Swedish unemployment insurance schemes, for example, are still essentially voluntarist. Denmark's labor movement has been chronically incapable of pursuing full employment policies due in part to trade union 
resistance to active manpower policies. And in both Denmark and Finland, the market has been allowed to play a decisive role in pensions.

Neither are the liberal regimes pure. The American social security system is redistributive, compulsory and far from actuarial. At least in its early formulation, the New Deal was as social democratic as was contemporary Scandinavian social democracy. In contrast, the Australian welfare state would appear exceedingly close to the bourgeois-liberal ideal-type, but much of its edifice has been the co-responsibility of Australian labor. And, finally, the European corporatist regimes have received both liberal and social democratic impulses. Social insurance schemes have been substantially de-stratified and unified in Austria, Germany, France and Italy. Their extremely corporativist character has thus been reduced.

Notwithstanding the lack of purity, if our essential criteria for defining welfare states have to do with the quality of social rights, social stratification, and the relationship between state, market and family, the world is composed of distinct regime-clusters. Comparing welfare states on scales of more or less or, indeed, better or worse, will yield highly misleading results.

THE CAUSES OF WELFARE STATE REgIMES

If welfare states cluster into three distinct regime types, we are confronted with a substantially more complex task of identifying the causes of welfare state differences. What is the explanatory power of industrialization, economic growth, capitalism, or 
working class political power in accounting for regime types? A first superficial answer would be: very little. The nations we study are all more or less similar with regard to all but the working class mobilization variable. And we find very powerful labor movements and parties in each of the three clusters. A theory of welfare state developments must clearly reconsider its causal assumptions if we wish to explain clusters. The hope to find one single powerful causal motor must be abandoned; the task is to identify salient interaction effects. Based on the preceding arguments, three factors in particular should be of importance: the nature of (especially working-) class mobilization; class-political coalition structures; and the historical legacy of regime inst itutionalization.

As we have noted, there is absolutely no compelling reason to believe that workers will automatically and naturally forge a socialist class identity; nor is it plausible that their mobilization will look especially Swedish. The actual historical formation of working class collectivities will diverge, and so also will their aims and political capacities. Fundamental differences appear both in trade unionism and party development. A key element in trade unionism is the mix of craft and industrial unions. The former is prone to particularism and corporativism; the latter is inclined to articulate broader, more universal objectives. This blend decisively affects the scope for labor party action and also the nature of political demands. Thus, the dominance of the AFL in pre-war United States was a major impediment to social policy development. Likewise, the heavily craftoriented Danish labor movement, compared to its Norwegian and Swedish counterparts, blocked social democracy's aspirations for an active labor market policy for full 
employment. In the United States, craft unions believed that negotiating occupational benefits was a superior strategy, given their privileged market position. In Denmark, craft unions jealously guarded their monopoly on training and labor mobility. Conversely, centralized industrial unionism will tend to present a more unified and consolidated working class clientele to the labor party, making policy consensus easier, and power mobilization more effective. It is clear that a working class mobilization thesis must pay attention to union structure.

Equally decisive is political or denominational union fragmentation. In many nations, for example Finland, France and Italy, trade unionists are divided between socialist and communist parties; white collar unions are politically unaffiliated or divide their affiliation among several parties. Denominational trade unionism has been a powerful feature in Holland, Italy and other nations. Since trade unionism is such a centrally important basis for party mobilization, such fragmentation will weaken the left and thus benefit the non-socialist parties' chances of power. In addition, fragmentation may entail that welfare state demands will be directed to many parties at once. The result may be less party conflict over social policy, but it may also mean a plurality of competing welfare state principles. For example, the subsidiarity principle of Christian workers will conflict with the socialists' concern for the emancipation of women.

The structure of trade unionism may, or may not, be reflected in labor party formation. But, under what conditions are we likely to expect certain welfare state 
outcomes from specific party configurations? There are many factors that conspire to make it virtually impossible to assume that any labor, or left, party will ever be capable, single-handedly, of structuring a welfare state. Denominational or other divisions aside, it will be only under extraordinary historical circumstances that a labor party alone will command a parliamentary majority long enough to impose its will. We have noted that the traditional working class has, nowhere, ever been an electoral majority. It follows that a theory of class mobilization must look beyond the major leftist party. It is an historical fact that welfare state construction has depended on political coalition building. The structure of class coalitions is much more decisive than are the power resources of any single class.

The emergence of alternative class coalitions is, in part, determined by class formation. In the earlier phases of industrialization, the rural classes usually constituted the single largest electorate. If social democrats wanted political majorities, it was here that they were forced to look for allies. Therefore, it was ironically the rural economy that was decisive for the future of socialism. Where the rural economy was dominated by small, capital intensive family farmers, the potential for an alliance was greater than where it rested on large pools of cheap labor. And, where farmers were politically articulate and well-organized (as in Scandinavia), the capacity to negotiate political deals was vast ly superior.

The role of the farmers in coalition formation and, hence, in welfare state development is clear. In the Nordic countries, the conditions obtained for a broad 
red-green alliance for a full-employment welfare state in return for farm price subsidies. This was especially true in Norway and Sweden, where farming was highly precarious and dependent on state aid. In the United States, the New Deal was premised on a similar coalition (forged by the Democratic party) but with the important difference that the labor intensive South blocked a truly universalistic social security system, and opposed further welfare state developments. In contrast, the rural economy of Continental Europe was very inhospitable to red-green coalitions. Often, as in Germany and Italy, much of agriculture was 1 abor intensive and labor unions and left parties were seen as a threat. In addition, the conservative forces on the continent had succeeded in incorporating farmers into "reactionary" alliances, helping to consolidate the political isolation of labor.

Political dominance was, until after World War II, largely a question of rural class politics. The construction of welfare states in this period was, therefore, dictated by which force captured the farmers. The absence of a red-green alliance does not necessarily imply that no welfare state reforms were possible. On the contrary, it implies which political force came to dominate their design. Great Britain is an exception to this general rule, because the political significance of the rural classes eroded before the turn of the century. In this way, Britain's coalition logic showed at an early date the dilemma that faced most other nations later, namely that the new white collar middle classes constitute the linchpin for political majorities. The consolidation of welfare states after World War II came to depend fundamentally on the political alliances of the new middle classes. For social democracy, the challenge was to synthesize working class- and white collar demands 
without sacrificing the commitment to solidarity.

Since the new middle classes have, historically, enjoyed a relatively privileged position in the market, they have also been quite successful in meeting their welfare demands outside the state or, as civil servants, by privileged state welfare. Their employment security has traditionally been such that full employment has been a peripheral concern. Finally, any program for drastic income equalization is likely to be met with great hostility among a middle class clientele. on these grounds, it would appear that the rise of the new middle classes would abort the social democratic project and strengthen a liberal welfare state formula.

The political position of the new middle classes has, indeed, been decisive for welfare state consolidation. Their role in shaping the three welfare state regimes described earlier is clear. The Scandinavian model relied almost entirely on social democracy's capacity to incorporate them in a new kind of welfare state: one that provided benefits tailored to the tastes and expectations of the middle classes, but nonetheless retained universalism of rights. Indeed, by expanding social services and public employment, the welfare state participated directly in manufacturing a middle class instrumentally devoted to social democracy.

In contrast, the Anglo-Saxon nations retained the residual welfare state model precisely because the new middle classes were not wooed from the market into the state. In class terms, the consequence is dualism. The welfare state caters essentially to the working class, and to the poor. Private insurance and occupational fringe benefits cater to the middle classes. Given the 
electoral importance of the latter, it is quite logical that further extensions of welfare state activities are resisted. Indeed, the most powerful thrust in these countries is an accent on fiscal welfare; i.e. on tax expenditures and deductions for private sector welfare plans.

The third, Continental European, welfare state regime has also been patterned by the new middle classes, but in a different way. The cause is historical. Developed by conservative political forces, these regimes institutionalized a middle class loyalty to the preservation of both occupationally segregated social insurance programs and, ultimately, to the political forces that brought them into being. Adenauer's great pension reform in 1957 was explicitly designed to resurrect middle class loyalties.

\section{CONCLUSION}

We have here presented an alternative to a simple class mobilization theory of welfare state development. It is motivated by the analytical necessity of shifting from a linear to an interactive approach with regard to both welfare states and their causes. If we wish to study welfare states, we must begin with a set of criteria that define their role in society. This role is certainly not to spend or tax; nor is it necessarily that of creating equality. We have presented a framework for comparing welfare states that takes into consideration the principles for which the historical actors willingly have struggled and mobilized. And, when we focus on the principles embedded in welfare states, we discover distinct regime clusters, not merely variations of "more" 
or "less" around a common denominator.

The salient forces that explain the crystallization of regime differences are interactive. They involve, first, the pattern of working class political formation and, second, the structuration of political coalitions with the historical shift from a rural economy to a middle class society. The question of political coalition formation is decisive.

Third, past reforms have contributed decisively to the institutionalization of class preferences and political behavior. In the corporatist regimes, hierarchical status-distinctive social insurance cemented middle-class loyalty to a peculiar type of welfare state. In the liberal regimes, the middle classes became institutionally wedded to the market. And, in Scandinavia, the fortunes of social democracy after the war were closely tied to the establishment of a middle class welfare state that benefits both its traditional working class clientele and the new white collar strata. In part, the Scandinavian social democrats were able to do so because the private welfare market was relatively undeveloped and, in part, because they were capable of building a welfare state with features of sufficient luxury to satisfy the tastes of a more discriminating public. This also explains the extraordinarily high cost of Scandinavian welfare states.

But, a theory that seeks to explain welfare state growth should also be able to understand its retrenchment or decline. It is typically believed that welfare state backlash movements, tax revolts, and roll-backs are ignited when social expenditure burdens become too heavy. Paradoxically, the opposite is true. Anti-welfare state 
sentiments over the past decade have generally been weakest where welfare spending has been heaviest, and vice-versa. Why?

The risks of welfare state backlash depend not on spending, but on the class character of welfare states. Middle class welfare states, be they social democratic (as in Scandinavia) or corporatist (as in Germany), forge middle class loyalties. In contrast, 1 iberal, residualist welfare states found in the United States, Canada and, increasingly, Britain depend on the loyalties of a numerically weak, and often politically residual social stratum. In this sense, the class coalitions in which the three welfare states were founded, explain not only their past evolution but also their future prospects. 
NOTES

1. Adam Smith is often cited but rarely read. A closer inspection of his writings reveals a degree of nuance and a battery of reservations that substantially qualify a delirious enthusiasm for the blessings of capitalism.

2. In the wealth of Nations (Smith, 1961:II:236), he comments on states that uphold the privilege and security of the propertied as follows: "...civil government, so $f a r$ as it is instituted for the security of property, in reality instituted for the defence of the rich against the poor, or of those who have some property against those who have none at all".

3. This tradition is virtually unknown to Anglo-Saxon readers, since so little has been translated into English. A key text which greatly influenced public debate and later social legislation was Adolph Wagner's, Rede Ueber die Soziale Frage (1872). For an English language overview of this tradition of political economy, see Schumpeter (1954), and especially Bower (1947).

From the Catholic tradition, the fundamental texts are the two Papal Encyclicals, Rerum Novarum (1891) and Quadrogesimo Anno (1931). The social Catholic political economy's main advocacy is a social organization where a strong family is integrated in cross-class corporations, aided by the state in terms of the subsidiarity principle. For a recent discussion, see Richter (1987).

Like the liberals, the conservative political economists also have their contemporary echoes, although substantially fewer in number. A revival occurred with Fascism's concept of the Corporative ("Standische") state of Ottmar Spann in Germany. The subsidiarity principle still guides much of German Christian Democratic politics (see Richter, op.cit).

4. Chief proponents of this analysis are the German "state derivation" school (Muller \& Neususs, 1973); Offe (1972); O'Connor (1973); Gough (1979); and also the work of Poulantzas (1973). As Skocpol and Amenta (1986) note in their excellent overview, the 
approach is far from one -dimensional. Thus, offe, 0 'Connor and Gough identify the function of social reforms as being also concessions to mass demands and as potentially contradictory.

Historically, socialist opposition to parliamentary reforms was principled less by theory than by reality. August Bebel, the great leader of German social democracy, rejected Bismarck's pioneering social legislation, not because he did not favour social protection, but because of the blatantly anti-socialist and divisionary motives behind Bismarck's reforms.

5. This realization came from two types of experiences. one, typified by Swedish socialism in the 1920s, was the discovery that not even the working class base showed much enthusiasm for socialization. In fact, when the Swedish socialists established a special commission to prepare plans for socialization, it concluded after 10 years of exploration that it would be practically quite impossible to undertake. $A$ second $k$ ind of experience, typified by the Norwegian socialists and Blum's Popular Front government in 1936, was the discovery that radical proposals could easily be sabotaged by the capitalists' capacity to withhold investments and export their capital abroad.

6. This is obviously not a problem for the parliamentary class hypothesis alone; structural Marxism faces the same problem of specifying the class character of the new middle classes. If such a specification fails to demonstrate that it constitutes a new working class, both varieties of Marxist theory face severe (although not identical) problems.

7. This literature has been reviewed in great detail by a number of authors. See, for example, wilensky et al. (1985), For excellent and more critical evaluations, see Uusitalo (1984), Shalev (1983) and Skocpol \& Amenta (1986).

8. This section derives much of its material from earlier writings (see, es̀pecially Esping-Andersen, $1985 \mathrm{a} ; 1985 \mathrm{~b} ; 1987$ ). 
REFERENCES

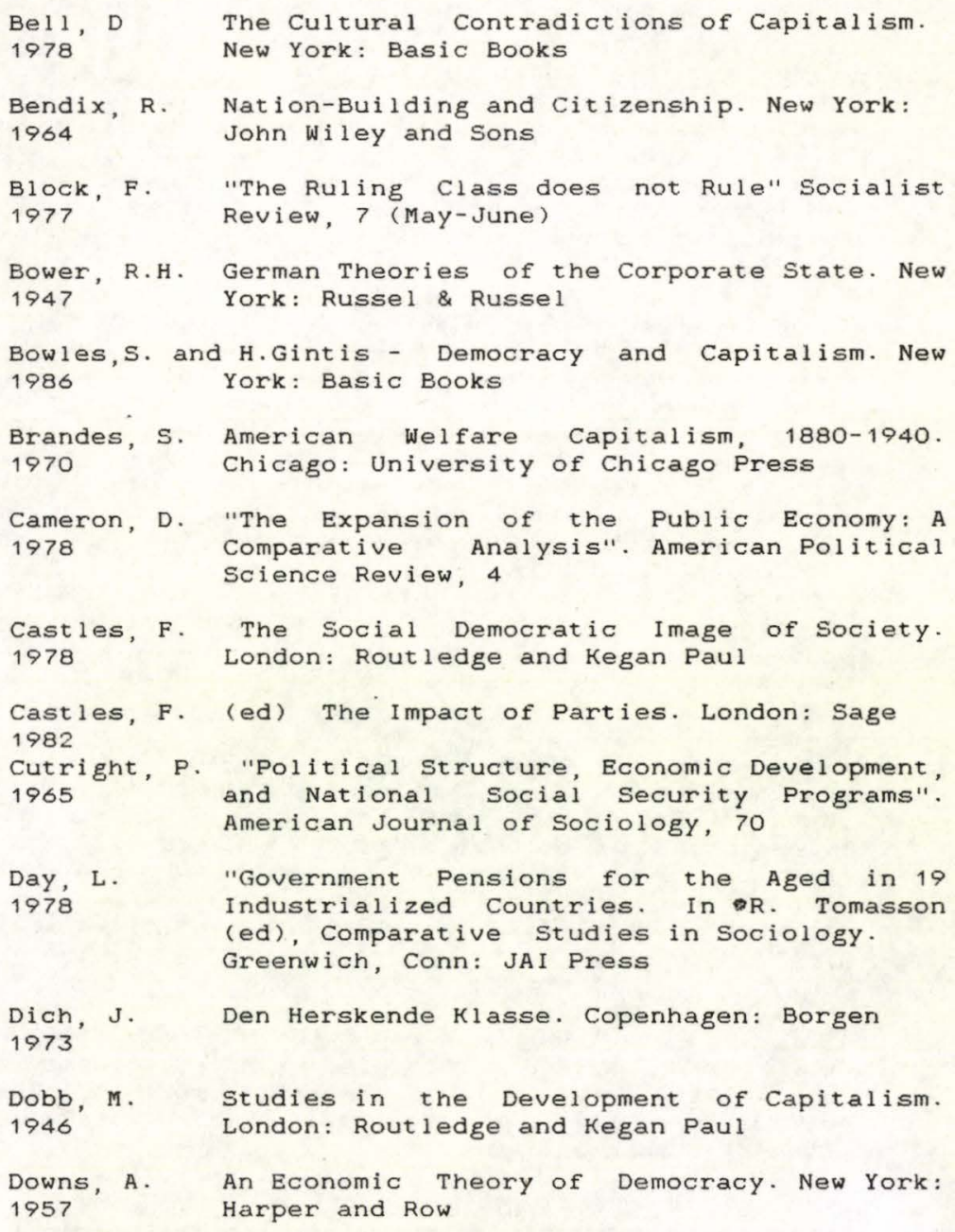

Esping-Andersen, G. - Politics against Markets. 1985a Princeton: Princeton University Press 
Esping-Andersen, G. - "Power and Distributional $1985 \mathrm{~b} \quad$ Regimes". Politics and Society, 14

Esping-Andersen, G. - "Citizenship and Socialism: De1987 commodification and Solidarity in the welfare State". In M. Rein, G. Esping-

Andersen and L. Rainwater (eds), Stagnation and Renewal. Armonk, NY: M.E.Sharpe

Esping-Andersen, G. and R. Friedland - "Class Coalitions 1982 in the Making of West European Economies". Political Power and Social Theory, 3

Esping-Andersen, G. and W.Korpi - "Social Policy as Class 1984 Politics in Postwar Capitalism". In $\mathrm{J}$. Goldthorpe (ed), Order and Conflict in Contemporary Capitalism. Oxford: Oxford University Press

Esping-Andersen, G. and W. Korpi - "From Poor relief to 1986 Institutional welfare States". In R. Erikson et.al.(eds), The Scandinavian Model. Armonk, NY: M.E. Sharpe

Evans, E. Social Policy, 1830-1914. London: Routledge 1978 and Kegan Pail

Flora, P. and J.Alber - "Modernization, Democratization 1981 and the Development of Welfare States in Europe". In P. Flora and A. Heidenheimer (eds), The Development of Welfare States in Europe and America. London: Transaction Books

Flora, P. and A. Heidenheimer - The Development of 1981 Welfare States in Europe and America. London: Transaction Books

Gough, I. The Political Economy of the Welfare state. 1979 London: Macmillan

Gourevitch, P. - Politics in Hard Times. Ithaca, New 1986

York: Cornell University Press

Heimann, E. Soziale Theorie der Kapitalismus. Frankfurt: 1929 Suhrkamp ( 1980 reprint)

Hewitt, C. "The Effect of Political Democracy and 1977 Social Democracy on Equality in Industrial Societies". American Sociological Review, 42 


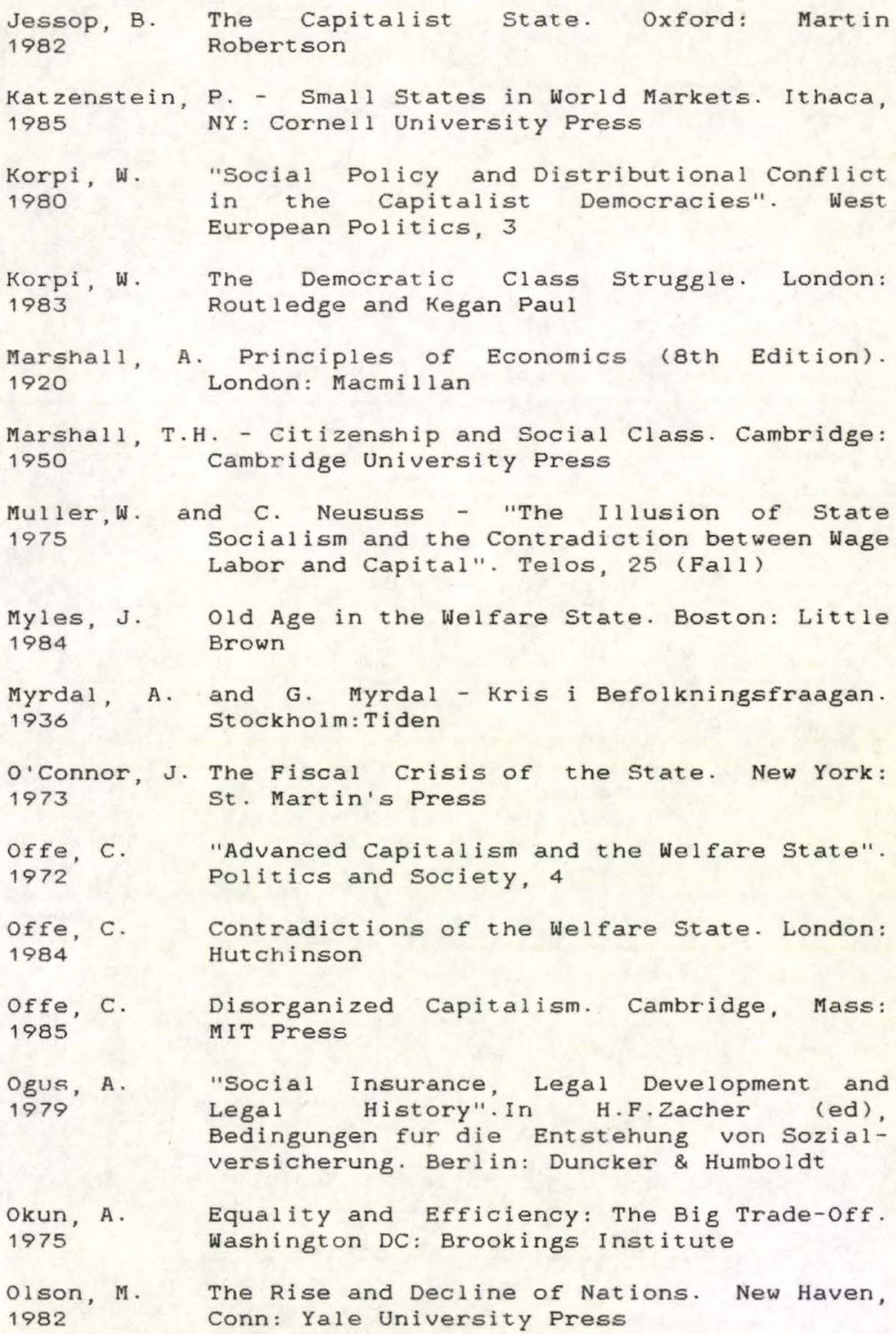


Polanyi, K.
1944 The Great Transformation. New York:

Poulantzas, $\mathrm{N}$ 1973

Pryor, F. 1969

Przworski, A 1980

Przworski, 1985

Richter, E 1987

Rimlinger, 1971

Robbins, L. 1976

Rokkan, $\mathrm{s}$. 1970

Schmidt, $\quad M$. 1982

Schmidt, M. 1983

\section{London: New Ieft Books}

and Social Classes.

Public Expenditures in Communist and Capitalist Nations. London: Allen and Unwin

A. - "Material Bases of Consent: Politics and Economics in a Hegemonic System". Political Power and Social Theory, 1

A. - Capitalism and Social Democracy. Cambridge: Cambridge University Press Politische Viertel jahresschrift, 28

G. Welfare and Industrialization in Europe, America and Russia. New York: John Wiley

Political Economy Past and Present. London: Macmi 11 an

Citizens, Elections, Parties. Oslo: Universitetsforlaget.

"The role of Parties in shaping Macroeconomic Policies". In F. Castles (ed), The Impact of Parties. London: Sage

"The welfare state and the Economy in periods of Economic Crisis". European Journal of Political Research, 11

Schmitter, P. and G. Lembruch - Trends toward Corporat ist 1979 Intermediation. London: Sage

Schumpeter, J, - Capitalism, Socialism and Democracy. 1944 London: Allen and Unwin

Schumpeter, J. - History of Economic Analysis. New York: 1954 Oxford University Press

Shalev, M. "The Socialdemocratic Model and Beyond". 1983 Comparative Social Research, 6

Shonfield, A. - Modern Capitalism. Oxford: Oxford 1965 University Press 


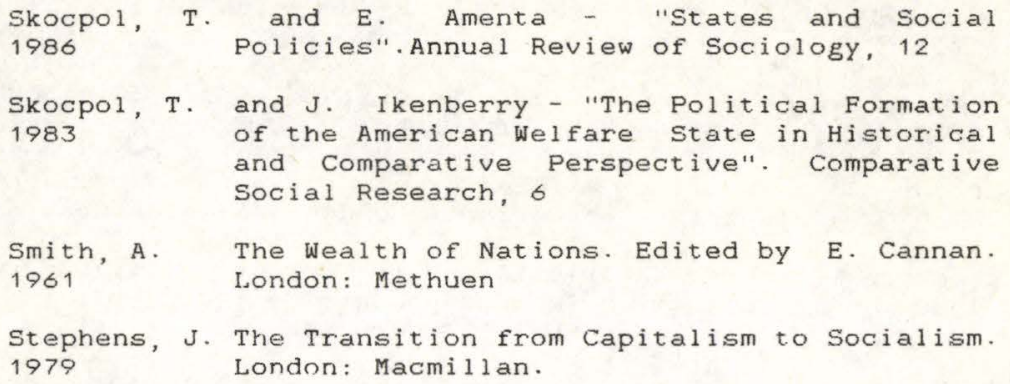

Weir, M. and Skocpol, T. - "State Structures and the 1985 Possibilities for "Keynesian" Responses to the Great Depression in Sweden, Britain, and the United States". In P. Evans et.al. (eds), Bringing the State Back In. New York: Cambridge University Press

Wilensky, $H$. The Welfare State and Equality. Berkeley, 1975

California: University of California Press 
Wilensky, H. "Leftism, Catholicism, and Democratic 1981 Corporatism". In P. Flora and A. Heidenheimer (eds), op.cit.

Wilensky, H. and C. Lebeaux - Industrial Society and 1958 Social Welfare. New York: Russell Sage

Wilensky, H. et al. - Comparative Social Policy: Theory, 1985 Methods, Findings. Berkeley: International Studies. Research Series, 62 



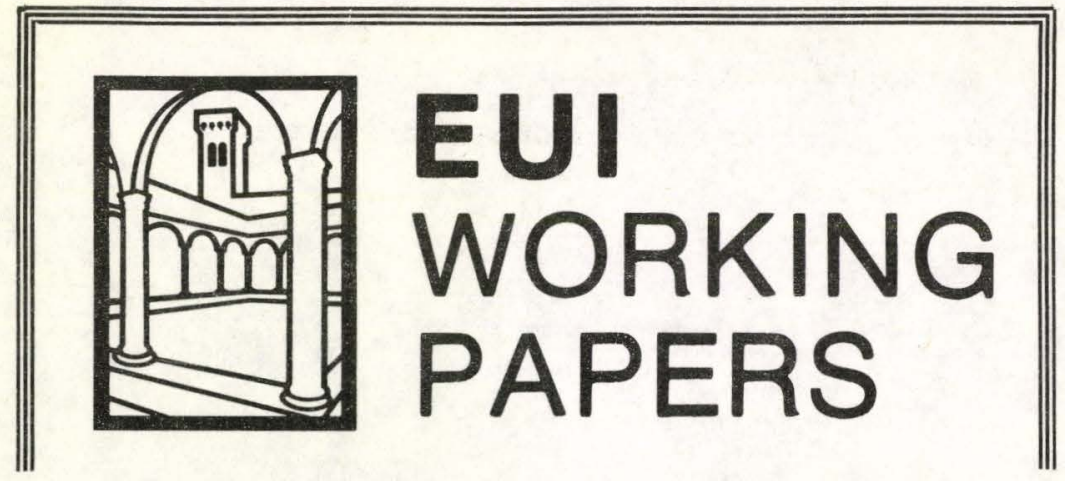

EUI Working Papers are published and distributed by the European University Institute, Florence.

A complete list and copies of Working Papers can be obtained free of charge - depending on the availability of stocks - from:

The Publications Officer

European University Institute

Badia Fiesolana

I - 50016 San Domenico di Fiesole (FI)

Italy 


\section{PUBLICATIONS OF THE EUROPEAN UNIVERSITY INSTITUTE}

To

The Publications Officer

European University Institute

Badia Fiesolana

I - 50016 San Domenico di Fiesole (FI)

Italy

From Name

Address

Please send me:

$\square \quad$ a complete list of EUI Working Papers

$\square \quad$ the following EUI Working Paper(s):

No:

Author, title:

Date: 
87/315: Serge NOIRET

87/316: Alain GOUSSOT

87/317: Eamonn NOONAN

87/318: Jean-Pierre CAVAILLE

87/319: Peter RAPPOPORT and Lucrezia REICHLIN

87/320: Douglas GALE

87/321: Gianna GIANNELLI

87/322: Keith PILBEAM

87/323: Alan KIRMAN

87/324: Andreu MAS-COLELL

88/325: Angela GROPPI

88/326: Bernd MARIN

88/327: Jean BLONDEL

88/328: Ida KOPPEN
Nuovi motivi per studiare $i$ meccanisni delle leggi elettorali. Una riflessione metodologica a proposito della legge del 1919 in Italia

Les sources internationales de la culture socialiste italienne à la fin du $19 \mathrm{e}$ siècle et au début du $20 \mathrm{e}$ siècle. Problèmes de la composition de l'idéologie du PSI et ses rapports avec la circulation des idées en Europe

Württemberg's exporters and German protection, 1931-36

Theatrum Mundi. Nozes sur la théatralité du Monde Baroque.

Segmented Trends and Nonstationary Time Series

A Strategic Model of Labor Markets with Incomplete Information

A Monopoly Union Model of the Italian Labour Market

Sterilization and the Profitability of UK Intervention 1973-86

The Intrinsic Limits of Modern Economic Theory

An Equivalence Theorem for a Bargaining Set

"La classe la plus nombreuse, la plus utile et la plus précieuse". Organizzazione del lavoro e conflitti nella Parigi rivoluzionaria.

Qu'est-ce que c'est "Le Patronat"? Quelques enjeux théoriques et observations empiriques

Decision-Making Processes, Conflicts, and Cabinet Government *

The European Community's Environment Policy.

From the Summit in Paris, 1972, to the Single European Act, 1987 * 
88/329: Dalia MARIN

88/330: Milica UVALIC

88/331: David CANNING

88/332: Dalia MARIN

88/333: Keith PILBEAM

88/334: Hans Ulrich Jessurun d' OLIVEIRA

88/335: Felix Fitzroy and Kornelius Kraft

88/336: Norbert LORENZ

88/337: Domenico Mario NUTI

88/338: Pietro REICHLIN and Paolo SICONOLFI

88/339: Alfred STEINHERR

88/340: Frederick VAN DER PLOEG

88/341: David CANNING

88/342: Gunther TEUBNER

88/343: Jean BLONDEL
Assessing Structural Change: The Case of Austria *

"Shareholding" in Yugoslav Theory and Practice

Convergence to Equilibrium in a Sequence of Games with Learning

Trade and Scale Economies. A causality test for the U.S., Japan, Germany and the UK

Fixed versus Floating Exchange Rates Revisited

Die EWG und die Versalzung des Rheins

Piece Rates with Endogenous Monitoring Some Theory and Evidence

Die Übertragung von Hoheitsrechten auf die Europäischen Gemeinschaften

- verfassungsrechtliche Chancen und Grenzen einer europäischen Integration erläutert am Beispiel der Bundesrepublik Deutschland, Frankreichs und Italiens -

On Traditional Cooperatives and James Meade's Labour-Capital Discriminating Partnerships

Government Debt and Equity Capital in an Economy with Credit Rationing

The EMS with the ECU at Centerstage: A proposal for reform of the European Exchange rate system

Monetary and Fiscal Policy in

Interdependent Economies with Capital Accumulation, Death and Population Growth

Optimal Monetary Policy in an Economy without a Forward Market for Labour

"And God Laughed..."

Indeterminacy, Self-Reference and Paradox in Law

Ministerial Careers in Western European Governments 
88/344: Joerg MAYER

88/345: Keith PILBEAM

88/346: Ef isio ESPA

88/347: Francesc MORATA and and Jaume VERNET

88/348: Milica UVALIC

88/349: Massimo PANEBIANCO

88/350: Gregorio ROBLES

88/351: Alan RIRMAN

88/352: Gianna GIANNELLI

88/353: Niall O'HIGGINS

88/354: Christian JOERGES

88/355: Summary of Conference, debates and abstracts of selected interventions

88/356: Mary MCCARTHY and Lucrezia REICHLIN

88/357: Richard M. GOODWIN

88/358: Fernando PACHECO Eric PEERE and Francisco S. TORRES

88/359: Jaakko NOUSIAINEN
Intervention Mechanisms and Symmetry in the EMS

Exchange Rate Management and the Risk Premium

The Structure and Methodology of International Debt Statistics

Las Asambleas Regionales en Italia y España: Organizacion Institucional $y$ Reglas de Funcionamiento

The Investment Behaviour of the Labour-Managed Firm: An Econometric Analys is

Inter-Regional Co-Operation in the North-South Dialogue

Lat in America and the European Community

La Cour de Justice des CE et les Principes Généraux du droit

On Ants and Markets

Labour Demand, Pricing and Investment Decisions in Italy: An Econometric Analysis

The Progressivity of Government Taxes and Benefits in Ireland: A Comparison of Two Measures of Redistributive Impact

Amerikanische und deutsche Traditionen der soziologischen Jurisprudenz und der Rechtskritik

The Future Financing of the EC Budget: EPU Conference :6-17 October 1987

Do Women Cause Unemployment?

Evidence From Eight O.E.C.D. Countries

Chaotic Economic Dynamics

Duopoly Under Demand Uncertainty

Substance and Styie of Cabinet Decision-Making 
88/360: Domenico Mario NUTI

88/361: Domenico Mario NUTI

88/362: Domenico Mario NUTI

88/363: Reiner GRUNDMANN

88/364: TONY PROSSER

88/365: Silke BRAMMER

88/366: Goesta ESPING-ANDERSEN

88/367: Goesta ESPING-ANDERSEN Paul FARSUND and Jon Eivind KOLBERG

88/368: Stephen MARTIN
Economic Relations between the European Community and CMEA

Remonetisation and Capital Markets in the Reform of Centrally Planned Economies

The New Soviet Cooperatives: Advances and Limitations

Marx and the Domination of Nature Alienation, Technology and Communism

The Privatisation of Public Enterprises in France and Great Britain The State, Constitutions and Public Policy

Die Rompetenzen der EG im Bereich Binnenmarkt nach der Einheitlichen Europäischen Akte

The Three Political Bconomies of the Welfare State

Decommodification and Work Absence in the Welfare State

Joint Ventures and Market Performance in 01 igopoly 